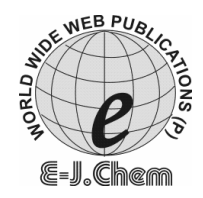

http://www.e-journals.net
ISSN: 0973-4945; CODEN ECJHAO

E-Journal of Chemistry

2009, 6(3), 775-779

\title{
Synthesis and Antimicrobial Activity of Some New 2-Substituted Benzothiazole Derivatives
}

\author{
B. RAJEEVA, N. SRINIVASULU and S. M. SHANTAKUMAR* \\ Department of Pharmaceutical Chemistry, \\ V. L. College of Pharmacy, \\ Raichur-584103, Karnataka, India. \\ jeevavlcp@yahoo.com
}

Received 8 January 2009; Accepted 10 March 2009

\begin{abstract}
Some new 2-(5-substituted-1,3,4-oxadiazole-2-yl)-1,3- benzothiazole (3a-j) were synthesized by refluxing benzothiazolyl carboxyhydrazide with different aryl acids in phosphoryl chloride. Structures of the synthesized compounds were established on the basis of ${ }^{1} \mathrm{H}$ NMR and Mass spectral data. The anti microbial activity of the synthesized compounds was evaluated by disc diffusion method.
\end{abstract}

Keywords: 1,3,4-Oxadiazole, Synthesis, Aryl acids and Antimicrobial activity.

\section{Introduction}

Substituted 1,3,4-oxadiazole are the heterocyclic system that have been found to exhibit diverse biological activities such as antibacterial ${ }^{1-3}$, antifungal ${ }^{4,5}$, anti-inflammatory ${ }^{6}$, analgesic ${ }^{7}$ and anticancer ${ }^{8,9}$ activity. Benzothiazoles are also found to be antimicrobial ${ }^{10}$, antifungal ${ }^{11,12}$, anticancer $^{13,14}$ and anti-inflammatory ${ }^{15,16}$ activity. These biological data prompted us to synthesize some new benzothiazole derivatives containing 1,3,4-oxadiazole ring.

\section{Experimental}

Melting points were determined in open capillary tubes and are uncorrected. ${ }^{1} \mathrm{H}$ NMR were recorded on Varian $200 \mathrm{MHz}$ and Brucker $400 \mathrm{MHz}$, Mass Spectra were recorded on LCMS Shimadzu spectrophotometer. The physical data of the synthesized compounds were presented in Table 1.

\section{Preparation of ethyl-2-benzothiazole carboxylate (1)}

Ethyl-2-benzothiazole carboxylate was synthesized by following method. A mixture of $o$-aminothiophenol $(0.1 \mathrm{~mol})$ and diethyl oxalate $(0.2 \mathrm{~mol})$ was heated at mild reflux for $4 \mathrm{~h}$, during which the temperature decreases from 147 to $93{ }^{\circ} \mathrm{C}$. After cooling, the mixture was 
poured into a solution consisting of $50 \mathrm{~mL}$ of conc hydrochloric acid, $150 \mathrm{~mL}$ of water and $70 \mathrm{~mL}$ of ethanol with stirring, the oil dissolved and a solid formed. The mixture was cooled. The product was filtered and washed with aq. Ethanol, then dried and finally crystallized from pet ether, yield 53\%, m.p. $68-70{ }^{\circ} \mathrm{C}$. ${ }^{1} \mathrm{H}$ NMR (DMSO): $\delta 1.4$ to $1.6(3 \mathrm{H}$, t, $\mathrm{CH}_{3}$ of $\left.-\mathrm{COOCH}_{2} \mathrm{CH}_{3}\right), 4.5$ to $4.7\left(2 \mathrm{H}, \mathrm{q}, \mathrm{CH}_{2}\right.$ of $\left.-\mathrm{COOCH}_{2} \mathrm{CH}_{3}\right), 7.5$ to $8.3(4 \mathrm{H}, \mathrm{m}, \mathrm{Ar}-\mathrm{H})$.

Table 1. Characterization of the compounds 3a-j.

\begin{tabular}{|c|c|c|c|c|c|}
\hline Compound & $\mathrm{R}$ & Mol. Formula & Mol. weight & Melting point ${ }^{\circ} \mathrm{C}$ & Yield, \% \\
\hline $3 \mathbf{a}$ & & $\mathrm{C}_{15} \mathrm{H}_{9} \mathrm{~N}_{3} \mathrm{OS}$ & 279 & $170-174$ & 75 \\
\hline $3 \mathbf{b}$ & & $\mathrm{C}_{15} \mathrm{H}_{8} \mathrm{BrN}_{3} \mathrm{OS}$ & 358 & $116-120$ & 68 \\
\hline $3 c$ & & $\mathrm{C}_{16} \mathrm{H}_{11} \mathrm{~N}_{3} \mathrm{O}_{2} \mathrm{~S}$ & 309 & $190-194$ & 73 \\
\hline 3d & & $\mathrm{C}_{15} \mathrm{H}_{8} \mathrm{ClN}_{3} \mathrm{OS}$ & 313 & $170-174$ & 65 \\
\hline $3 e$ & & $\mathrm{C}_{14} \mathrm{H}_{8} \mathrm{~N}_{4} \mathrm{OS}$ & 280 & $176-180$ & 68 \\
\hline $3 f$ & & $\mathrm{C}_{17} \mathrm{H}_{11} \mathrm{~N}_{3} \mathrm{OS}$ & 305 & $190-192$ & 61 \\
\hline $3 g$ & & $\begin{array}{c}\mathrm{C}_{16} \mathrm{H}_{9} \mathrm{Cl}_{2} \mathrm{~N}_{3} \mathrm{O}_{2} \\
\mathrm{~S}\end{array}$ & 378 & $138-142$ & 60 \\
\hline $3 h$ & & $\mathrm{C}_{15} \mathrm{H}_{7} \mathrm{~N}_{5} \mathrm{O}_{5} \mathrm{~S}$ & 369 & $200-202$ & 65 \\
\hline $3 \mathbf{i}$ & & $\mathrm{C}_{17} \mathrm{H}_{13} \mathrm{~N}_{3} \mathrm{O}_{2} \mathrm{~S}$ & 323 & $60-64$ & 62 \\
\hline $3 \mathbf{j}$ & & $\mathrm{C}_{15} \mathrm{H}_{9} \mathrm{ClN}_{4} \mathrm{OS}$ & 328 & $192-196$ & 66 \\
\hline
\end{tabular}

Preparation of 1, 3-benzothiazole-2-carboxyhydrazide (2)

In to a clean dry $100 \mathrm{~mL}$ round bottomed flask, the ethyl-2-benzothiazole carboxylate (1) (0.01 mole) was dissolved in ethanol $(60 \mathrm{~mL})$. The hydrazine hydrate $(0.02$ mole) $(99 \%)$ was added drop by drop with constant stirring and the content were refluxed for $8 \mathrm{~h}$, cooled to room temperature. The solid separated was filtered and washed with water, dried and finally crystallized from ethanol, yield $80 \%$, m.p. $172-174{ }^{\circ} \mathrm{C}$. ${ }^{1} \mathrm{H}$ NMR (DMSO): $\delta 4.6$ to 4.8 (2H, s, $\mathrm{NH}_{2}$ of $\left.-\mathrm{CONH} . \mathrm{NH}_{2}\right), 7.5$ to $8.3(4 \mathrm{H}, \mathrm{m}, \mathrm{Ar}-\mathrm{H}), 10.4$ to10.6 (1H, s, NH of -CONH.NH$\left.{ }_{2}\right)$. 


\section{Preparation of 2-(5-substituted-1,3,4-oxadiazole-2-yl)-1,3-benzothiazole (3a-j)}

A mixture of 1, 3-benzothiazole-2-carboxyhydrazide (2) $(0.01 \mathrm{~mol})$, appropriate aromatic acid $(0.02 \mathrm{~mol})$ and phosphoryl chloride $(10 \mathrm{~mL})$ was refluxed on water bath for 6-8 hours. After cooling to room temperature it was poured into the crushed ice with stirring. The solid thus obtained was filtered, washed with water and crystallized from ethanol to give compounds 3a-j (Scheme 1).

3a: ${ }^{1} \mathrm{H}$ NMR $\left(\mathrm{CDCl}_{3}\right): \delta 7.5-7.8(9 \mathrm{H}, \mathrm{m}, \mathrm{Ar}-\mathrm{H}) .3 \mathbf{a ~} \mathrm{m} / \mathrm{z}$ : Molecular ion peak at 279. 3b ${ }^{1} \mathrm{H}$ NMR $\left(\mathrm{CDCl}_{3}\right): \delta 7.3-8.2(8 \mathrm{H}, \mathrm{m}, \mathrm{Ar}-\mathrm{H}) .3 \mathrm{c}{ }^{1} \mathrm{H} \mathrm{NMR}\left(\mathrm{CDCl}_{3}\right): \delta 3.9\left(3 \mathrm{H}, \mathrm{s},-\mathrm{OCH}_{3}\right), 7.0-$ $8.2(8 \mathrm{H}, \mathrm{m}, \mathrm{Ar}-\mathrm{H}) .3{ }^{1} \mathrm{H}$ NMR $\left(\mathrm{CDCl}_{3}\right): \delta$ 7.4-8.2 (8H, m, Ar-H). 3d $\mathrm{m} / \mathrm{z}:\left(\mathrm{m}^{-1}\right)$ Molecular ion peak at 312. 3e ${ }^{1} \mathrm{H}$ NMR (DMSO): $\delta$ 7.5-8.4 (8H, m, Ar-H). $3 \mathrm{f}^{1} \mathrm{H}$ NMR $\left(\mathrm{CDCl}_{3}\right): \delta$ 7.4$8.0(9 \mathrm{H}, \mathrm{m}, \mathrm{Ar}-\mathrm{H}), 8.0-8.1(1 \mathrm{H}, \mathrm{d}, \mathrm{H}$ of $-\mathrm{CH}=\mathrm{CH}), 8.2-8.4(1 \mathrm{H}, \mathrm{d}$, of $-\mathrm{CH}=\mathrm{CH}) .3 \mathrm{~g}{ }^{1} \mathrm{H}$ NMR (DMSO): $\delta$ 5.7-5.8 (2H, s, $\left.-\mathrm{CH}_{2}\right), 7.1-8.4(7 \mathrm{H}, \mathrm{m}, \mathrm{Ar}-\mathrm{H})$.

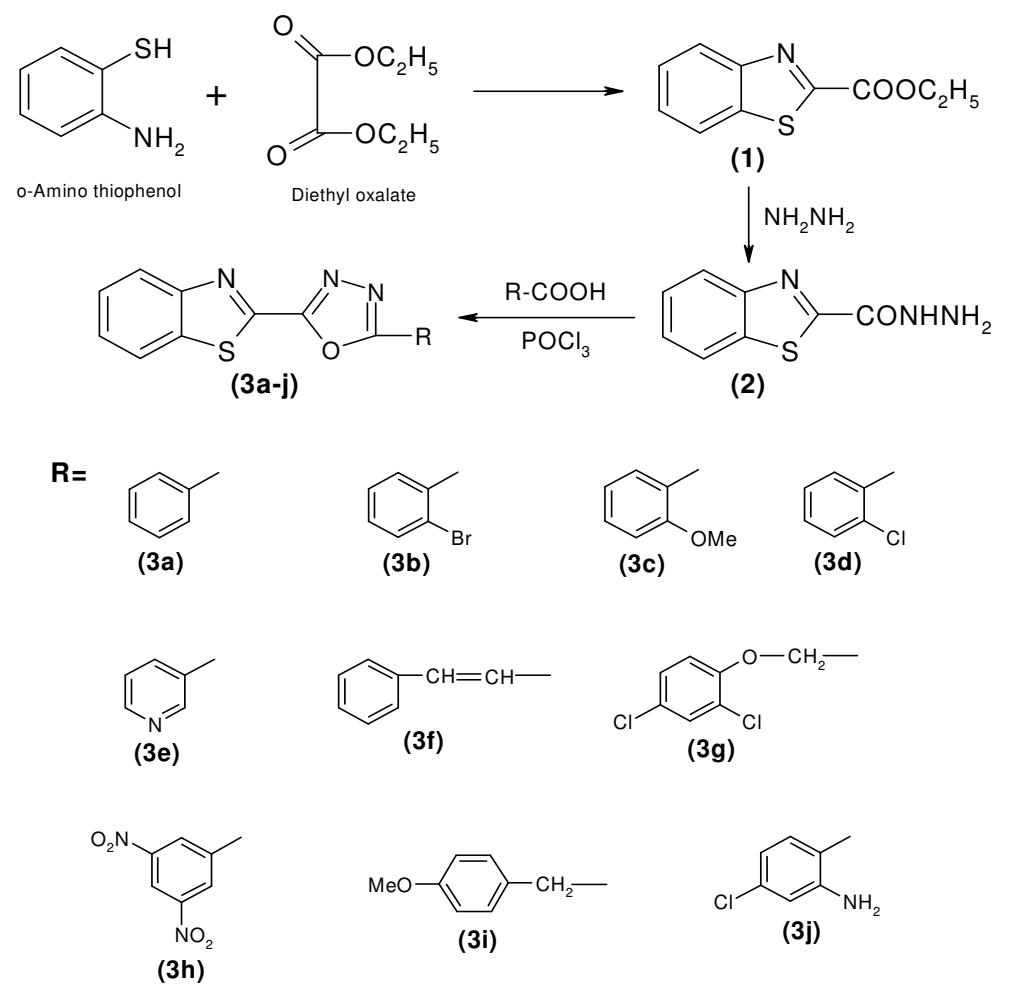

\section{Scheme 1}

\section{Antibacterial activity}

All the newly synthesized compounds (3a-j) were evaluated for in vitro antibacterial activity against gram positive and gram negative bacterial strains such as Bacillus subtilis, Bacillus pumilus, Escherichia coli and Pseudomonas aureginosa at concentration $100 \mu \mathrm{g} / \mathrm{mL}$ by disc diffusion method ${ }^{17}$ by using DMSO as solvent control and nutrient agar was employed as culture media. After $24 \mathrm{~h}$ of incubation at $37{ }^{\circ} \mathrm{C}$, the zone of inhibition were measured in $\mathrm{mm}$. The activity was compared with known antibiotic ciprofloxacin and the data was represented in the Table 2 . 
Table 2. Antibacterial activity of compounds 3a-j.

\begin{tabular}{ccccc}
\hline & \multicolumn{4}{c}{ " Inhibition of zone diameter in mm } \\
\cline { 2 - 5 } Sample & B. subtilis & B. pumillis & E. coli & P. aeruginosa \\
\cline { 2 - 5 } code & $100 \mu \mathrm{g}$ & $100 \mu \mathrm{g}$ & $100 \mu \mathrm{g}$ & $100 \mu \mathrm{g}$ \\
\hline 3a & 14 & 15 & 15 & 14 \\
3b & 19 & 21 & 20 & 21 \\
3c & 13 & 15 & 15 & 15 \\
3d & 20 & 20 & 21 & 20 \\
3e & 15 & 16 & 15 & 16 \\
3f & 16 & 16 & 17 & 15 \\
3g & 21 & 21 & 23 & 20 \\
3h & 22 & 23 & 20 & 21 \\
3i & 14 & 16 & 15 & 16 \\
3j & 15 & 17 & 16 & 15 \\
Ciprofloxacin & 24 & 25 & 24 & 24 \\
DMSO & - & - & - & - \\
\hline
\end{tabular}

*Each value is an average of three independent determination \pm Standard deviation. Note: '-' denotes no activity, 8-12 mm poor activity, 13-17 mm moderate activity, 18-20 mm and above good activity.

\section{Conclusion}

All the 10 newly synthesized compounds were screened for antibacterial activity studies at a concentration of $100 \mu \mathrm{g} / \mathrm{mL}$ using DMSO as a control and ciprofloxacin used as standard against gram positive and gram negative bacteria. The data in the Table 2 indicates that among the synthesized compounds $\mathbf{3 b}, \mathbf{3 d}, \mathbf{3 g}$ and $\mathbf{3 h}$ compounds was found to posses a broad spectrum activity. However, the activities of the tested compounds are much less than those of standard antibacterial agents used.

\section{Acknowledgements}

The authors are thankful to the Management of V. L. College of Pharmacy, Raichur for providing the necessary facilities to carry out this work. Authors also extend their thanks to IISc Bangalore for providing ${ }^{1} \mathrm{H}$ NMR spectra analysis.

\section{References}

1. Hu G Q, Xie S Q, Xu Q J, Huang W L, Zhang H B and Huang S T, Yao Xue Xue Bao, 2005, 40, 337-339.

2. Karabasanagouda T, Adhikari, Airody V, Shetty and Suchetha N, Phosp Sulf and Silicon, 2007, 182, 2925-2941.

3. Guang F Y, Zu Ming L I U and Xiang H Q, Chin Chem Lett., 2001, 12, 877-880.

4. Fang L, Luo X O, Song B A, Bhadury P S, Song Y, Jin L H, Weixue and Hu D Y, Bioorg Med Chem., 2008, 16, 3632-3640.

5. Cai J C, Bao A S, Song Y, Guang F X, Pinaki S B, Lin H Jin, De Y H, Qian Z L, Fang L, Wei X, Ping L and Zhuo C, Bioorg Med Chem., 2007, 15, 3981-3989.

6. Jakubkiene V, Burbuliene M M, Mekuskiene G, Udrenaite E, Gaidelis P and Vainilavicius P, IL Farmaco, 2003, 58, 323-328.

7. Harish K, Sadique A J, Suroor A K and Mohammad A Eur J Med Chem., 2008, 43, 2688-2698.

8. Linhong J, Jiang C, Baoan S, Zhuo C, Song Y, Qianzhu L, Deyu H and Ruiqing X Bioorg Med Chem Lett., 2006, 16, 5036-5040. 
9. Ahmed S A, Hamdy M A R, Nadia M M and Mahmoud A E G, Bioorg Med Chem., 2006, 14, 1236-1246.

10. Kucukbav H, Cetinkava E and Durmaz R, Arzneim Forsch, 1995, 45, 1331-1334.

11. Pattan S R, Narendra B S N and Angadi J S, Indian Drugs, 2002, 39, 515-517.

12. Ameya A C and Nandini R P, Molecules, 2007, 12, 2467-2477.

13. Caleta I, Grdisa M, Mrvos D S, Cetina M, Tralic K V, Pavelic K and Karminski G IL Farmaco, 2004, 59, 297-305.

14. Geoffrey W, Tracey D B, Patrizia D, Angela S, Dong F S, Andrew D W and Malcolm F G S, Bioorg Med Chem Lett., 2000, 10, 513-515.

15. Naik P R, Pandeya S N and Pandey A, Indian J Physiol Pharmacol., 1996, 40, 189-190.

16. Sushilkumar S B and Devanand B S, J Korean Chem Soc., 2003, 47, 237-240.

17. Cruickshank R, Duguid J P, Marmion B P and Swam H A, The Practice of Medical Microbiology; $12^{\text {th }}$ Ed., Churchill Livingstone, London, 1975, p. 544. 


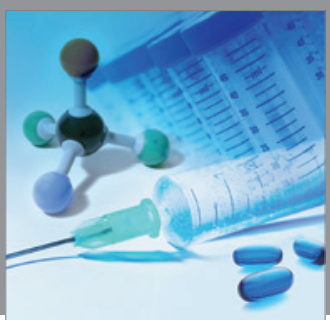

International Journal of

Medicinal Chemistry

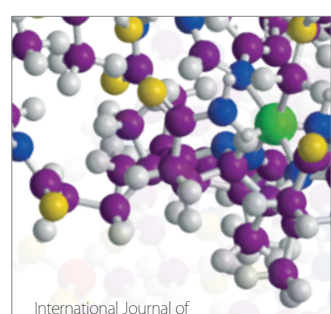

Carbohydrate Chemistry

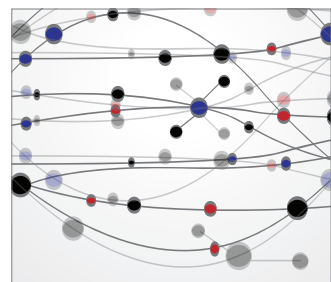

The Scientific World Journal
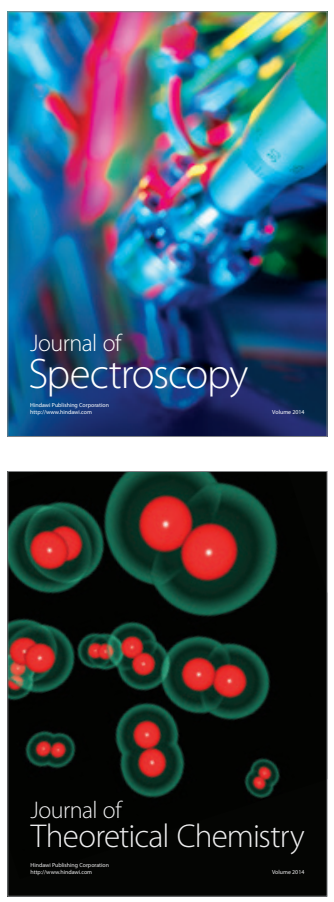
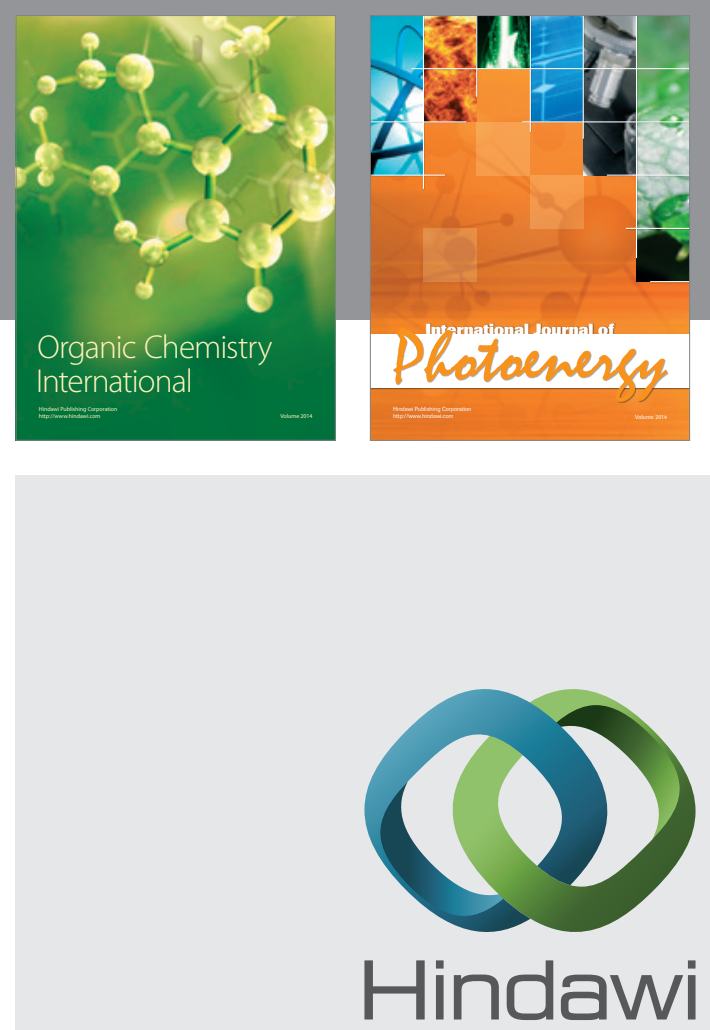

Submit your manuscripts at

http://www.hindawi.com
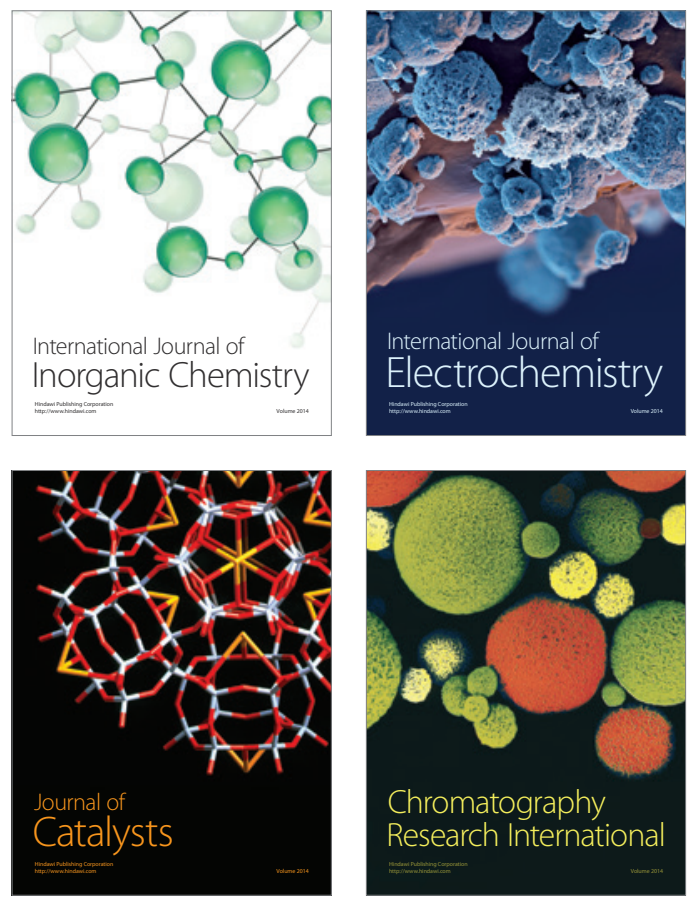
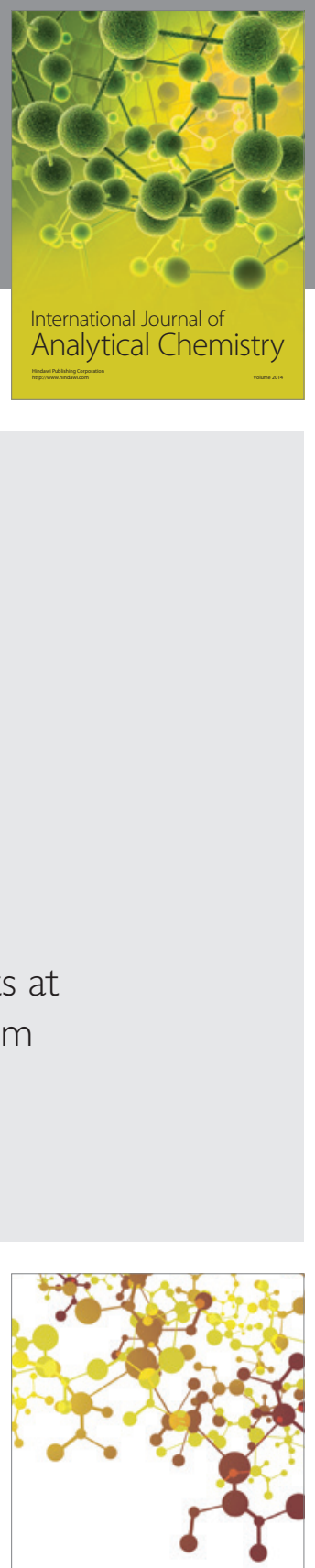

Journal of

Applied Chemistry
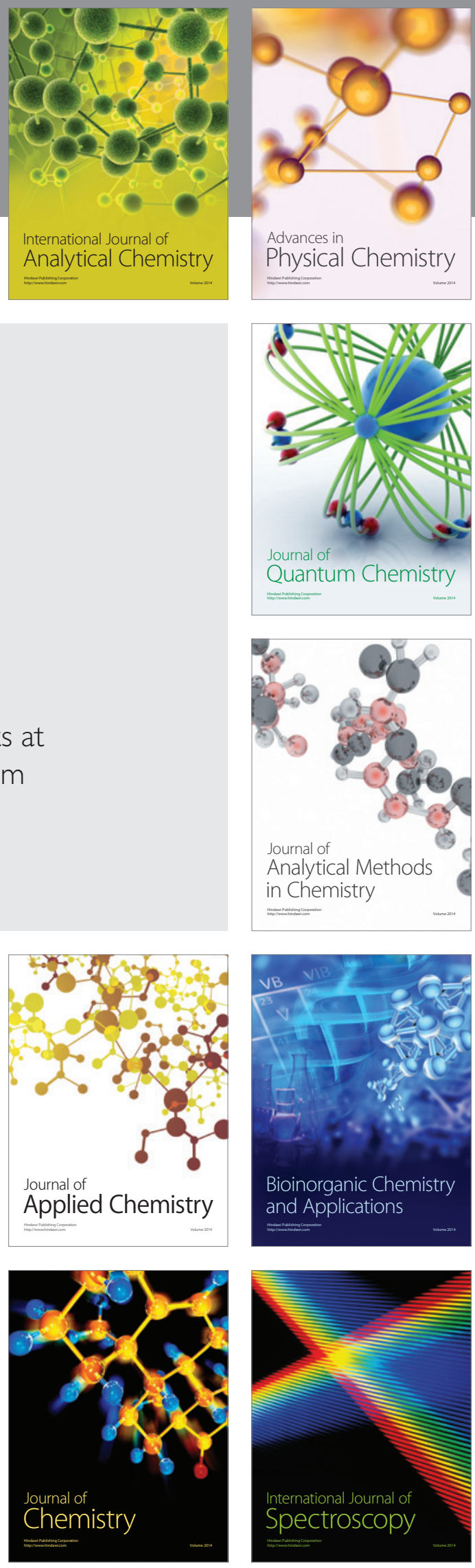